Acta Horticulturae et Regiotecturae 1

Nitra, Slovaca Universitas Agriculturae Nitriae, 2020, pp. 5-7

\title{
SWEET CHERRY FRUIT CHARACTERISTIC IN COVERED ORCHARDS
}

\author{
Radek VÁVRA \\ Research and Breeding Institute of Pomology Holovousy Ltd., Czech Republic
}

\begin{abstract}
The aim of evaluations performed in experimental plantings of the Research and Breeding Institute of Pomology Holovousy Ltd. was to verify the effect of covering systems on fruit characteristics - size, weight, firmness and soluble solids content (SSC). The research was focused on evaluation of fruit characteristics in 2017 and 2018 on fourteen cultivars: 'Amid', 'Cristiana', 'Early Korvik', 'Elza', 'Fabiola', 'Felicita', Horka', 'Justyna', 'Kasandra', 'Kordia', 'Korvik', 'Tamara', 'Těchlovan' and 'Vanda'. The tested cultivars were grown in an IPM irrigated covered orchard. The largest fruit size was recorded for the cultivar 'Tamara' with $29.5 \mathrm{~mm}$ followed by the cultivar 'Horka' with $29 \mathrm{~mm}$ and 'Felicita' with $28.6 \mathrm{~mm}$. The greatest weight was recorded for the cultivar 'Tamara' with $12.4 \mathrm{~g}$ followed by 'Felicita' with $12.3 \mathrm{~g}$. The greatest firmness was recorded in fruits of the cultivar 'Amid' with index 77.5 and 'Tamara' with index 73.2. High correlation between fruit characteristics was found only between weight and size of fruits (correlation coefficient 0.88). High differences were recorded between years. In 2017, fruits characteristics were higher (size $27.5 \mathrm{~mm}$, weight $10.9 \mathrm{~g}$, firmness 65.3 , SSC $19.3^{\circ}$ Brix) while in 2018, fruit characteristics were lower (size $26.5 \mathrm{~mm}$, weight $9.2 \mathrm{~g}$, firmness 59.2 , SSC $16.5^{\circ}$ Brix).
\end{abstract}

Keywords: Prunus avium L.; fruit quality; fruit weight; fruit size; fruit firmness; soluble solid content

Modern sweet cherry orchards are equipped with covering systems against rain which affect the quality of the fruit in particular by reducing the rain-induced fruit cracking. The positive effect of covered plantings is also higher fruit size and weight which increases the price of cherries and marketability of production. Nowadays, retail chains and consumers demand high-sized cherries over $30 \mathrm{~mm}$ in the width of the fruits (Measham et al., 2014, Meland et al., 2014). This size can be achieved by using covering systems against rain. Information related to the specific conditions of growing cherries in covered plantings, supplemented with knowledge about technologies of protection against major diseases and pests is essential for cherry growers. Higher quality and better marketability production from covered plantings is proved by ever-increasing areas of these systems in Europe and in all other continents. The most commonly used systems in practice include Haygrove tunnels (www. haygrove.com), and single-row systems e.g. VOEN system (www.voen.de). Other systems, such as retractable roof technology (www.cravo.com), are also used in North and South America. Regardless of the type of covering systems, the main objective is to achieve the harvest of high market quality fruits. The influence of the VOEN system on the quality of cherries was evaluated at the location Holovousy in the Research and Breeding Institute of Pomology, Czech Republic. The results are presented in this paper.

\section{Material and method}

The research was focused on covered experimental cherry plantings at the location Holovousy. Climatic conditions of
Holovousy are characterized by average annual temperature of $8.1^{\circ} \mathrm{C}$ and average annual rainfall of $655 \mathrm{~mm}$. The soil was medium loam sandy with rather deep cultivated layer on gravel substrate. The orchard was located at the altitude of 300-370 masl. Experimental trees were trained as spindles using strong wooden stakes as supports. Clean strips were kept under the trees by contact herbicides whereas frequently cut sod was kept in alleys between the tree rows. Fertilizers were applied according to soil analyses. Spraying treatment against pests and diseases was conducted based on recommendations used for commercial orchards. The tested cultivars were grown in an IPM covered orchard. Irrigation was applied in the covered orchard. The experiments were focused on sweet cherry fruit characteristics.

The aim of the experiments performed in 2017-2018 was to verify the effect of covering systems (company VOEN, Germany) on cultivar differences in fruit weight, fruit size, fruit sweetness (soluble solids content; SSC) and fruit firmness. In this evaluation there were involved cultivars 'Amid', 'Early Korvik', 'Elza', 'Fabiola', 'Felicita', 'Horka', 'Christiana', 'Justyna', 'Kasandra', 'Kordia', 'Korvik', 'Tamara', 'Těchlovan' and 'Vanda'.

The fruits were harvested at the ripening time according to the individual cultivars. The samples were transferred to the laboratory and evaluated immediately. In each sample, 25 fruits were evaluated for each genotype in two replicates. Fruit weight in grams, fruit size (width in diameter) in millimetres, fruit soluble solids content (SSC) in Brix and fruit firmness were recorded. SSC was measured using a digital refractometer HI 96801 (HANNA Instruments, USA), fruit firmness by a Durofel instrument (Copa-Technology, France)

Contact address: Radek Vávra, Research and Breeding Institute of Pomology Holovousy Ltd., Holovousy 129, 50801 Hořice, Czech Republic; e-mail: radek.vavra@vsuo.cz 
by index of 1-100 (with 100 being the maximum firmness), weight on a digital scale Kern 440-49N (KERN \& SOHN GmbH, Germany), and fruit width by digital callipers. All data were statistically processed by an analysis of variance by STATISTICA software (version 12, Stat Soft). Significant differences between the means for each sweet cherry cultivars were determined by the Tukey's test at $p<0.05$. The mutual dependence of two measured characteristics of individual fruits in all evaluated

Table1 Evaluation of sweet cherry cultivars in 2017 and 2018

\begin{tabular}{|l|c|c|c|c|}
\hline Cultivar & $\begin{array}{c}\text { Weight } \\
(\mathbf{g})\end{array}$ & $\begin{array}{c}\text { Size } \\
(\mathbf{m m})\end{array}$ & $\begin{array}{c}\text { SSC } \\
\text { ('Brix) }\end{array}$ & $\begin{array}{c}\text { Firmness } \\
\text { (index 1-100) }\end{array}$ \\
\hline Amid & $8.0 \mathrm{~g}$ & $24.8 \mathrm{hi}$ & $19.1 \mathrm{ab}$ & $77.5 \mathrm{a}$ \\
\hline Cristiana & $9.7 \mathrm{def}$ & $27.7 \mathrm{bcd}$ & $20.2 \mathrm{a}$ & $61.7 \mathrm{bcd}$ \\
\hline Early Korvik & $10.0 \mathrm{def}$ & $27.0 \mathrm{de}$ & $17.4 \mathrm{bcd}$ & $58.7 \mathrm{~cd}$ \\
\hline Elza & $10.3 \mathrm{cde}$ & $27.3 \mathrm{~cd}$ & $18.7 \mathrm{abc}$ & $66.3 \mathrm{~b}$ \\
\hline Fabiola & $10.5 \mathrm{cde}$ & $26.9 \mathrm{de}$ & $17.4 \mathrm{bcd}$ & $57.2 \mathrm{~d}$ \\
\hline Felicita & $12.3 \mathrm{ab}$ & $28.6 \mathrm{ab}$ & $15.1 \mathrm{e}$ & $64.6 \mathrm{bc}$ \\
\hline Horka & $10.0 \mathrm{ab}$ & $29.0 \mathrm{ab}$ & $18.0 \mathrm{abcd}$ & $63.6 \mathrm{bc}$ \\
\hline Justyna & $9.9 \mathrm{def}$ & $26.8 \mathrm{def}$ & $18.4 \mathrm{abc}$ & $59.0 \mathrm{~cd}$ \\
\hline Kasandra & $7.8 \mathrm{~g}$ & $24.4 \mathrm{i}$ & $16.3 \mathrm{de}$ & $42.7 \mathrm{e}$ \\
\hline Kordia & $10.6 \mathrm{~cd}$ & $26.4 \mathrm{defg}$ & $19.0 \mathrm{ab}$ & $57.5 \mathrm{a}$ \\
\hline Korvik & $9.5 \mathrm{ef}$ & $26.0 \mathrm{efg}$ & $17.1 \mathrm{cde}$ & $62.2 \mathrm{bcd}$ \\
\hline Tamara & $12.4 \mathrm{a}$ & $29.5 \mathrm{a}$ & $18.3 \mathrm{abc}$ & $73.2 \mathrm{a}$ \\
\hline Těchlovan & $11.1 \mathrm{bc}$ & $28.2 \mathrm{bc}$ & $17.2 \mathrm{cde}$ & $64.5 \mathrm{~b}$ \\
\hline Vanda & $9.1 \mathrm{f}$ & $25.8 \mathrm{gh}$ & $19.7 \mathrm{a}$ & $63.1 \mathrm{bc}$ \\
\hline
\end{tabular}

Table 2 Correlation coefficients of fruit characteristics

\begin{tabular}{|l||c|c|c|c|}
\hline Fruit characteristic & Weight & Size & SSC & Firmness \\
\hline Weight & $\mathrm{x}$ & 0.88 & 0.53 & 0.35 \\
\hline Size & 0.88 & $\mathrm{x}$ & 0.33 & 0.38 \\
\hline SSC & 0.53 & 0.33 & $\mathrm{x}$ & 0.33 \\
\hline Firmness & 0.35 & 0.38 & 0.33 & $\mathrm{x}$ \\
\hline
\end{tabular}

Table 3 Differences between years

\begin{tabular}{|l||c|c|c|c|}
\hline Year & Weight $\mathbf{( g )}$ & Size (mm) & SSC ( ${ }^{\circ}$ Brix) & Firmness (index 1-100) \\
\hline \hline $\mathbf{2 0 1 7}$ & $10.9 \mathrm{a}$ & $27.5 \mathrm{a}$ & $19.3 \mathrm{a}$ & $65.3 \mathrm{a}$ \\
\hline $\mathbf{2 0 1 8}$ & $9.2 \mathrm{~b}$ & $26.5 \mathrm{~b}$ & $16.5 \mathrm{~b}$ & $59.2 \mathrm{~b}$ \\
\hline
\end{tabular}

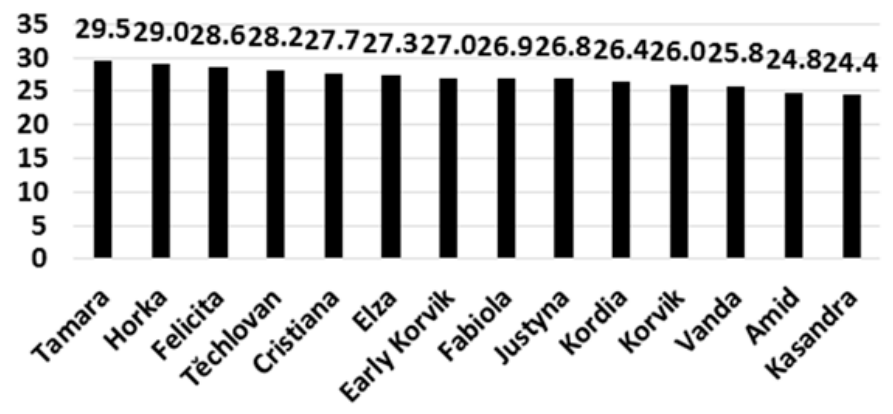

Figure 1 Evaluation of fruit size $(\mathrm{mm})$

cultivars is expressed by correlation coefficients.

\section{Results and discussion}

The results of the evaluation are shown in tables 1-3 and Figs 1-4.

\section{Fruit size}

Fruit size was higher in 2017 with the mean value of $27.5 \mathrm{~mm}$ than in 2018 with the mean value of $26.6 \mathrm{~mm}$. The biggest fruits were recorded for the cultivar 'Tamara' ( $29.7 \mathrm{~mm}$ ) followed by the cultivars 'Horka' and 'Felicita' with $29.0 \mathrm{~mm}$ and $28.6 \mathrm{~mm}$, respectively.

\section{Fruit weight}

Fruit weight was higher in 2017 (10.9 g) than in 2018 (9.2 g). Year on year differences in the weight of the fruit were observed mainly in the cultivars 'Amid', 'Korvik' and 'Vanda'. The weight of the cultivar 'Amid' was by $25.1 \%$ lower in $2018(6.8 \mathrm{~g})$ than in 2017 $(9.1 \mathrm{~g})$. The same phenomenon was observed for 'Korvik' with the weight by $24.8 \%$ lower in 2018 ( $8.2 \mathrm{~g})$ than in 2017 (10.9 g). The weight of the cultivar 'Vanda' was also lower by $25.2 \%$ in 2018 (7.8 g) than in 2017 (10.4 g). The greatest weight was recorded for the cultivar 'Horka' in 2017 (12.9 g). In both years, the cultivar 'Tamara' had the biggest fruit weight (12.4 g). In 2017, the smallest fruit weight was recorded by the cultivar 'Kasandra' (7.8 g).

\section{Fruit firmness}

Fruits were less firm (59.2) in 2018 than in 2017 (65.3). The greatest firmness was recorded for 'Tamara' in 2017 (82.7). In 2018, the highest fruit firmness was found for 'Amid' (74.5). On the contrary, the lowest firmness of 41.2 was recorded for the cultivar 'Kasandra' in 2018 and 44.2 in 2017.

\section{SSC}

Higher fruit sweetness was recorded in 2017 (19.3 $3^{\circ}$ Brix) than in 2018 (16.5 Brix). This observation can be explained by hot weather during ripening in 2018. Fruits ripened very quickly and it had the impact on lower fruit sweetness and also fruit size (both weight and width). 


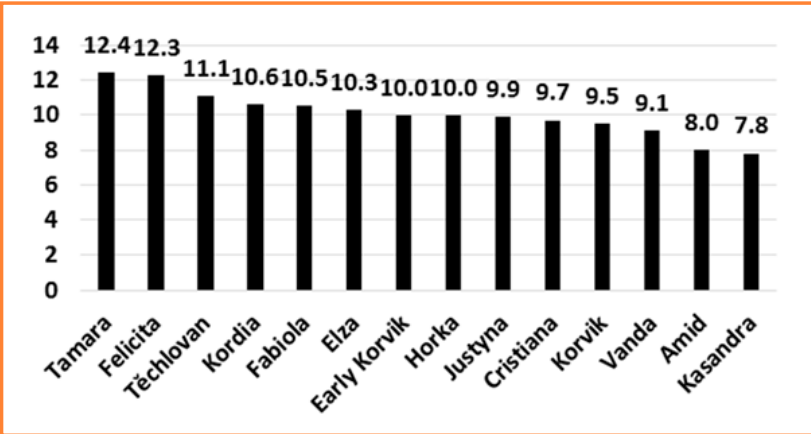

Figure 2 Evaluation of fruit weight $(\mathrm{g})$

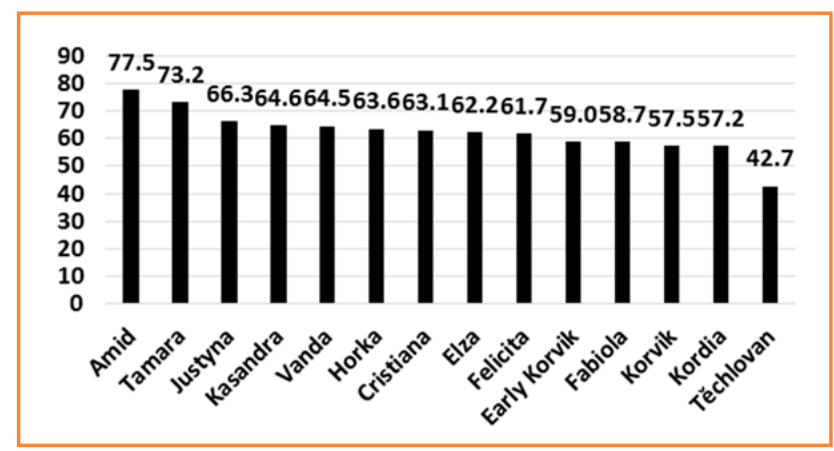

Figure 3 Evaluation of fruit firmness (index 1-100)

\section{Correlation between fruit characteristics}

High correlation between fruit characteristics (table 2) was found only between weight and width of fruits (correlation coefficient 0.88). This dependence can be described using the linear regression function $y=0.9204 x-14.741$ (Figure 5). Medium dependence was found between the fruit weight and the fruit SSC (correlation coefficient 0.53 ). Low dependence was recorded in the relation fruit weight - fruit firmness (correlation coefficient 0.35), size - SSC (correlation coefficient 0.33 ) and size - firmness (correlation coefficient 0.38).

\section{Conclusion}

The results point to large year on year differences in fruit weight, size, SSC and firmness and also differences among the tested cultivars. In 2017, the fruits of all cultivars reached higher weight and fruit size than in 2018. The cause of the small yields in 2017 is frost damage during the tree flowering period; the fruit set was reduced. As a result of frost damage, the fruit set was lower in 2017 which was reflected in their higher weight and size. The lower weight and size of fruits in 2018 can be explained by very warm and dry weather, when the fruits of all cultivars ripened very quickly and the period was not long enough to grow to the size and weight as in 2017.

The records showed differences in fruit firmness between years and among the tested cultivars. Differences in fruit firmness among the cultivars indicate the differences in their cell structures, skin characteristics, compositions and/or respiration rates (Karacali, 2012). The highest sizes of fruits ( $29 \mathrm{~mm}$ and more) were achieved by the cultivars 'Tamara', 'Horka', and the newly registered cultivar 'Felicita'. The weight of fruits over $12 \mathrm{~g}$ was recorded in the cultivars

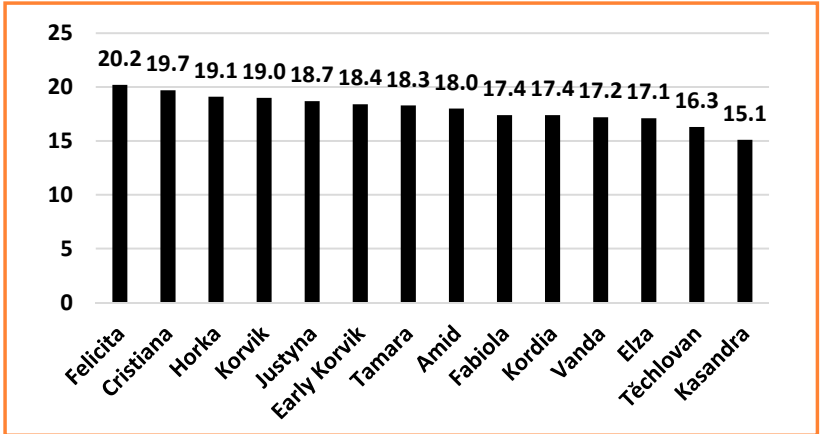

Figure 4 Evaluation of SSC ( ${ }^{\circ}$ Brix)

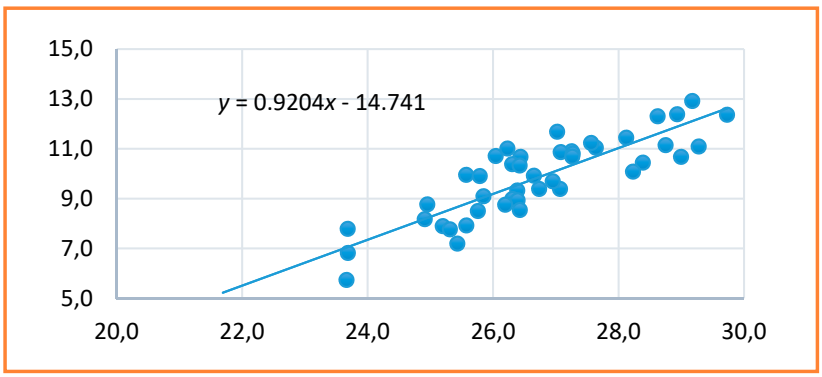

Figure 5 Dependence of fruit size and fruit weight

'Tamara', 'Horka' and 'Felicita', which confirms the high quality of the breeding programme of sweet cherries at Holovousy that is focused on selection and creation of high fruit size cherry cultivars. Fruit firmness of 'Amid' and 'Tamara' was higher than that of the other cultivars.

The differences in fruit characteristics among the cultivars observed in this evaluation of tested cultivars are in accordance with the observation of Sen et al., 2014 which includes differences in fruit quality during storage and transportation to consumers. Breeding programme and selection of new cultivars should be also focused on high ability of cherry fruits to long term storage and long shelf life.

\section{Acknowledgements}

This work is supported by the Ministry of Agriculture of the Czech Republic in the framework of the project QK1910296 with usage of the infrastructure of the project LO1608

\section{References}

KARACALI, I. 2012. Storage and marketing of horticultural products. Izmir, Turkey : Ege University Agricultural Faculty Publication, 2012, no. 494.

MEASHAM, P.F. - GRACIE, A.J. - WILSON, S.J. - BOUND, S.A. 2014. An alternative view of rain/inducted cracking of sweet cherries (Prunus avium L.). In Acta Horticulturae, 2014, no. 1020, pp. 217-222.

MELAND, M. - KAISER, C. - CHRISTENSEN, J.M.2014. Physical and chemical methods to avoid fruit cracking in cherry. In AgroLife Scientifi c Journal, vol. 3, 2014, no. 1, pp. 177-183.

FATIH, S. - RUSTU, O. - GOLKARIAN, M et al. 2014. Quality Changes of Different Sweet Cherry Cultivars at Various Stages of the Supply Chain. In Notulae Botanicae Horti Agrobotanici Cluj-Napoca. 42. 10.15835/nbha.42.2.959 